\title{
Overcoming fear? A search for an empowering theological response to the fear of witchcraft among urban Zimbabwean Christians
}

\begin{tabular}{|c|c|}
\hline \multicolumn{2}{|c|}{$\begin{array}{l}\text { Authors: } \\
\text { Collium Banda }^{1} \\
\text { Gift Masengwe }^{2}\end{array}$} \\
\hline \multicolumn{2}{|c|}{$\begin{array}{l}\text { Affiliations: } \\
{ }^{1} \text { Faculty of Theology, } \\
\text { North-West University, } \\
\text { South Africa }\end{array}$} \\
\hline \multicolumn{2}{|c|}{$\begin{array}{l}{ }^{2} \text { Department of Philosophy, } \\
\text { Practical and Systematic } \\
\text { Theology, University of } \\
\text { South Africa, South Africa }\end{array}$} \\
\hline \multicolumn{2}{|c|}{$\begin{array}{l}\text { Corresponding author: } \\
\text { Collium Banda, } \\
\text { collium@gmail.com }\end{array}$} \\
\hline \multicolumn{2}{|c|}{$\begin{array}{l}\text { Dates: } \\
\text { Received: } 30 \text { Dec. } 2017 \\
\text { Accepted: } 06 \text { Mar. } 2018 \\
\text { Published: } 29 \text { May } 2018\end{array}$} \\
\hline \multicolumn{2}{|c|}{$\begin{array}{l}\text { How to cite this article: } \\
\text { Banda, C. \& Masengwe, G., } \\
2018, \text { 'Overcoming fear? A } \\
\text { search for an empowering } \\
\text { theological response to the } \\
\text { fear of witchcraft among } \\
\text { urban Zimbabwean } \\
\text { Christians', Verbum et Ecclesia } \\
\text { 39(1), a1837. https://doi.org/ } \\
\text { 10.4102/ve.v39i1.1837 }\end{array}$} \\
\hline \multicolumn{2}{|c|}{$\begin{array}{l}\text { Copyright: } \\
\text { (c) 2018. The Authors. } \\
\text { Licensee: AOSIS. This } \\
\text { is licensed under the } \\
\text { Creative Commons } \\
\text { Attribution License. }\end{array}$} \\
\hline \multicolumn{2}{|l|}{ Read online: } \\
\hline 回象回 & $\begin{array}{l}\text { Scan this QR } \\
\text { code with your } \\
\text { smart phone or } \\
\text { mobile device } \\
\text { to read online. }\end{array}$ \\
\hline
\end{tabular}

How can we make theological sense of the resilience of the fear of witchcraft among indigenous Zimbabwean Christians? From the perspective of the transcendence and immanence of God, this article analyses the resilience of the fear of witchcraft among African Christians in Zimbabwe. The article uses results of a case study conducted in Zimbabwe in a congregation belonging to the Churches of Christ in Zimbabwe (COCZ) in the city of Bulawayo. Using focus group discussions and in-depth interviews, the study affirms that many African Christians struggle to overcome the fear of witchcraft in their lives. Witchcraft is feared because it is primarily viewed as an evil power that destroys life. The article analyses the awareness of witchcraft, the experiences of witchcraft and the responses to witchcraft among Zimbabwean Christians. The article proposes that African Christians be grounded on the transcendence and immanence of God as a way of overcoming the enduring fear of witchcraft.

Intradisciplinary and/or interdisciplinary implications: A meaningful response to the fear of witchcraft in Africa requires a multidisciplinary approach including phenomenology of religion, Christian doctrines and practical theology and pastoral care. The immanence and transcendency of God in a context of fear of witchcraft must be unpacked in the light of insights from phenomenology of religion, African traditional religions, discipleship and pastoral care.

\section{Introduction}

Belief in witchcraft is common even in modern Africa (Asamoah-Gyadu 2015:23; Osei 2003:6). Aspects of witchcraft feature prominently in some classical Ndebele literature works (Sibanda 1981; Sigogo 1962, 1967). Zimbabwe's news recently reported alleged incidents of witchcraft among both ordinary citizens and well-educated public leaders (Saunyama 2016; Mswazie 2017). In a classic case, former president Robert Mugabe accused his former deputies Joyce Mujuru and Emmerson Mnangagwa of using witchcraft to succeed him as presidents (Maza 2017; News24 2017). A few weeks before dismissing Mnangagwa as his deputy and subsequently accusing him of witchcraft, Mugabe and his wife Grace were accused of poisoning Mnangagwa at a Zimbabwe African National Union - Patriotic Front (ZANU-PF) youth rally. ${ }^{1}$ A news reporter quoted Mugabe responding to these accusations by sternly warning (Chikowore 2017):

Those who are accusing others in the party of witchcraft must know that it is unlawful to make such unfounded allegations. This is the reason why our colonisers enacted the Witchcraft Suppression Act which we are still using today. So if you dare call anyone a witch, we will make sure that you are arrested in terms of the law. (n.p.)

Mugabe's reference to the Witchcraft Suppression Act of $1899,{ }^{2}$ one of the earliest, now over a century old, piece of colonial law, enacted with white Christian missionary approval, demonstrates that attempts at modernisation, Westernisation and Christianisation have failed to eradicate pre-industrial beliefs in witchcraft. Circus allegations of use of witchcraft by national presidents who also advocate for science, technology, engineering and mathematics (STEM) show the persistence of fear of witchcraft even in the age of evidence-based knowledge. Osei (2003:13) observes that while belief in witchcraft was rife in pre-industrial rural communities of Europe, it waned as societies developed, but in modern Africa, witchcraft seems to hold on steadfastly.

1.While it may be worthy to distinguish whether these were counteraccusations of 'witchcraft' or 'sorcery', it will be pointed out below that the Ndebele and the Shona often do not make that distinction.

2.Chavunduka explains that the Witchcraft Act regarded both witchcraft and sorcery as superstition (1980:140) and consequently formal legal courts saw their job as eradicating the belief in witchcraft (1980:130). 
This article takes seriously the resilience of, and the disorientation witchcraft causes to people's faith (Asamoah-Gyadu 2015:23; Manala 2004:1491). This article is confined to the belief and fear of witchcraft among urban Christians; therefore, detailed intricacies of witchcraft fall outside the central focus of the article except where necessary. Furthermore, the issue of Satanism, which has attracted intense media attention in Zimbabwe (Biri \& Togarasei 2013:85; DailyNews 2015; The Chronicle 2017), was left out for a separate study. The article is interested in witchcraft as experienced by urbanites, who are assumed (rightly or falsely) to be more informed and culturally enlightened than their rural counterparts. The article focuses on urban Christians of the Churches of Christ in Zimbabwe (COCZ), one of the mainline mission churches in Zimbabwe. The article critically contemplates, from a systematic theological perspective, the enduring fear of witchcraft among urban Christians.

\section{Study background and methods}

Data for this article were obtained from the literature and fieldwork in an urban congregation of the COCZ in the city of Bulawayo. Ten participants (two young men aged 21-25 years, six women aged $25-45$ years and two men aged 45-70 years) participated in a focus group discussion (FGD). The young men had leadership responsibilities within the church's youth group. The six women included the pastor's wife; ministry group organizing secretary; women's fellowship chairlady, her deputy and secretary; and a youth advisor. The two men interviewed served as elders. Therefore, all the respondents were lay leaders. The researchers were not involved in selecting the participants. The participants were recruited by the congregation's pastor who offered his congregation in response to the researchers' request to the COCZ Bulawayo pastors' fraternity to interview Christians with experiences in witchcraft. The pastor responded by offering his congregation. The pastor did not attend the FGD because of pastoral commitments. Selecting those within the leadership of the congregation, instead of mixing ordinary church members and leaders, may lead to skewed results. However, insights gleaned from lay church leaders have their own independent merit that can be confirmed or disputed by a separate study among ordinary members in the pew. The purpose of the study was explained to the participants and informed consent was requested and granted. The participants were advised that they had the right to withdraw from the discussions for any reason of their own.

Churches of Christ in Zimbabwe belongs to a worldwide family of churches originating from the 18th Century Restoration Movement (RM) and the Second Great Awakening in America, who rejected denominationalism and tried to restore the Christian church to its pristine, New Testament forms. The names Churches of Christ, Christian Churches and Disciples of Christ provocatively assume and emphasise ownership of the church and its members by Christ. ${ }^{3}$ The movement rejected all party names and opted to be called Christians only. The church emphasises that there is no other earthly leader but Christ, no other creed but the Bible, among other claims. In this way, the church claims to be non-denominational, in reaction to 16th century splinter movements and bitter divisions of the Protestant Reformation to Catholicism. Ironically, restoration efforts have resulted in further fragmentations, the three common streams being the acappella stream (conservative and/or non-instrumental that rejects the use of musical instruments in church worship as unscriptural), the instrumental (that welcomes the use of musical instruments in worship) and the International Church of Christ (newer stream with a unique emphasis on disciple-making). Fascinatingly, while seemingly sternly opposed to all denominational aspects, COCZ has a church uniform for its women comprising white hats, red blouses and white skirts. Among the notable common practices of the Churches of Christ are the emphasis on baptism by immersion at Christian conversion, the weekly observance of the Lord's Supper and the priesthood of all believers.

The COCZ congregation in which this study was conducted belongs to the instrumental group. In Zimbabwe, the COCZ is one of the mainline groups of churches that arrived in the country in the late 1800s to early 1900s through the missionary efforts by New Zealanders, and later North Americans. The COCZ built several educational and health centres across the nation. However, the unfortunate emphasis on natural causes of sickness and death failed to tap into the African psyche on human existence, to organically address questions of superstition and witchcraft. This gap motivated this study, and attempts were made to engage urban COCZ Christians on this phenomenon to address deep-rooted attitudes and beliefs among African Christians.

\section{Witchcraft-fear and vulnerability in African traditional worldviews}

To meaningfully address the enduring phenomenon of the fear of witchcraft among African Christians, the question of vulnerability to spiritual powers in the African traditional religious (ATR) worldview, imbedded in the African psyche, has to be addressed first. Muchumayeli Bhebhe, a Zimbabwean Church of Christ theologian, observes that Africans suffer from an 'overpowering "fear of the spirit world"' (Bhebhe 2013:52). This fear is overbearing to 'an extent that even after several generations of Christianity, such fear continues to be a motivating force in the lives of some [Christians]' (Bhebhe 2013:52). Many Christians attest to continued dominance of ATR perspectives in their postconversion lives.

This article attempts not only to understand the resilience of fearing witchcraft but also the whole spectrum of the African psyche on the spiritual realm. The Ndebele and Shona traditions have a dichotomous worldview of the spiritual realm.

3.Casey and Foster (2002), Murch (2004) and Baker (2009) provide a detailed history on the origins and theological tenets of the Church of Christ and the Restoration Movement. 
Two intensely divided and competing spiritual worlds of the good and the evil exist. The good is controlled by the Supreme Being, creator God, uNkulunkulu (Ndebele) or Mwari (Shona). The Supreme Being occupies the apex of the hierarchy and good ancestors serve as his vice-regents, mediating between the supreme deity and humanity. However, the opposing forces of the evil world are dreaded, for they are believed to be saturated with a myriad of destructive evil spirits to humanity (Bhebhe 2013:54). While Bhebhe's (2013:52-56) designation of the good spiritual world as the above world and the negative world as the underworld seems to reflect a more of biblical Christian framework (cf. 1 Pt 3:19; Jacobs 2001:26, 31), dreaded evil spirits, such as the water mermaid spirits, umlambo (Ndebele) and njuzu (Shona), are believed to belong to the underworld, as they live under the waters. It is believed that the underworld is the abode of various harm-inflicting powers such as witchcraft, goblins, avenging spirits (uzimu or ngozi) and wandering spirits of dead people (amadlozi or mashave) that possess the people and lead them into anti-social acts such as stealing, murdering and sexual immorality. However, the human beneficiaries of these evil spirits view them positively; therefore, some sections may view positively the evil spirit that gives the skill for stealing or prostitution because of the money and wealth associated with it (Bhebhe 2013:54). ${ }^{4}$ But owing to fear of these evil spirits, Africans invest great efforts and wealth to ensure maximum protection (Manala 2004:1501; Mbiti 1969:99; Nyathi 2001:21).

Paradoxically, Africans also fear the good spirits because they have the power to punish for any offense and disobedience. Harms therefore do not only come from evil spirits but from angry good spirits as well. Quite often, it is believed that when the good spirits are offended, they withdraw their protection to allow harmful spirits to torment offenders. Consulting diviners helps to establish reasons as to why the good spirits may have withdrawn, and how to amend the offenses. For this reason, the Shona of Zimbabwe see 'a causal connection between the moral condition of the community and its physical environment' (Taringa 2006:194). In this case, some spiritual powers are seen as neutral, and it depends on the moral and spiritual dispositions of the individual to be issued rewards or harms. ${ }^{5}$ Traditional Zimbabweans believe that certain places are sacred, Ndebele ukuzila or Shona kuyera. Taringa (2006) justifiably states:

Among the Shona the real owner of the land and all on it is the tutelary spirit, Mwari and the various territorial ancestor spirits. So the environment belongs to the spirits. It is sacred (kuyera). Land is sanctified by its possession by the ancestor spirits whose remains are buried in it. So it is the spirits who look after their property. (p. 194)

Thus, certain geographically unique places are considered sacred, and not to be traversed without following appropriate

4.Therefore, some evil actions among traditional Ndebele and Shona are viewed not as simply a lack of self-control but also a result of evil spiritual influence, hence it is common to hear Shona people referring to a habitual thief as one aneshavi rewumbava.

5.According to Mbiti, 'the African peoples know that the universe has a power, or force or whatever else one may call it, in addition to the living-dead, spirits and the Supreme Being' (1969:197). procedures. If procedures are not followed, such as rituals, one can be disoriented while there and get lost (isidzimila in Ndebele; cha/chi-dzimira, in Shona) or even be untraceable owing to total disappearance. Zimbabwe's scenic Inyangani Mountains, a prime haven for local and international tourists have had such tragic and unresolved cases of untraceable disappearances (Mapimhidze 2014; Swancer 2017; The Standard 2014). Comments from locals relate the disappearances to victims' untoward behaviour towards unique features or elements in the mountains. Stories abound of uncompleted government and commercial projects such as road, bridge or dam construction until traditional rituals and ceremonies were conducted to diffuse the mysterious resistance.

Further, in ATR, vulnerability thrives on unpredictability, as one cannot predict the malevolent actions of the offended spirits. In other words, one cannot ascertain whether their suffering is from evil forces of witchcraft or offended good spirits. Not all disappearances, for instance, in sacred mountains or capture by mermaid (water) spirits, have reportedly been resolved by traditional appeasement ceremonies. However, the greatest fear in the psyche of an ordinary African is the human inability to control these spiritual forces (Bhebhe 2013:55-56). Thus, the unpredictability of these spiritual forces creates in an African psyche a 'continued craving for power, safety, protection and life, that is dictated to by the traditional worldview, [which] keeps on influencing [their] behavioural patterns' (Bhebhe 2013:52). Unpredictability is managed by human maintenance of harmonious relationships with the spirit world. Harmony creates equilibrium between the material and spirit world, making the world safe for human beings. Therefore, humans are conscientised against unnecessarily provoking good spirits to avoid their wrath, or antagonising evil powers, to avoid their terror. ${ }^{6}$

Related to the disconcerting fear of vulnerability to witchcraft is one's susceptibility to be turned into a witch. There is a strong belief that witchcraft is hereditary (Bozongwana 1983:40; Parrinder 1976:124). The Ndebele and Shona recognise that witchcraft can be consciously and voluntarily acquired. However, there are stories of unconscious and involuntary initiation into the practice of witchcraft. Therefore, spiritual protection is sought to cover one from being a victim or a practitioner. Safeguards are sought firstly from defence mechanisms by wearing magical instruments like amulets around necks, arms, legs and waists; incisions marks on their bodies through which powerful medicines are deposited into their blood to protect them from, and to counter, the effects of witchcraft, which Nyathi (2001:21) calls 'missilerepellents'. Secondly, Africans endear themselves with their ancestors for protection. In other words, vulnerability to witchcraft essentially occurs within vulnerability in the broader realm of the spirit world, which demands that the theological framework for responding to witchcraft and its 6.The ethical dilemma of this fear is that it has not averted the commission of some of the most heinous crimes in Africa. 
associated consequences must address the broader aspects of the spirit world.

\section{The overwhelming destructive evil power of witchcraft}

A theological response to the fear of witchcraft needs to take a broader framework of fear that is associated with the destructive powers of witchcraft to life. For this reason, people accused of witchcraft were mercilessly dealt with in the past owing to the fear of the lethal potential in the act of witchcraft (Chavunduka 1980:129-130; Nyathi 2001:20). In fact, the Witchcraft Suppression Act of 1899 primarily arose as a measure of ending the brutal treatment of people accused of witchcraft. However, in addition to treating witchcraft as mere superstition, the act ultimately viewed the African belief in witchcraft as caused by evil, jealousy, scapegoating, backbiting and hatred which resulted in accusers presenting themselves as 'consumable' victims of their enemies (Van Rooy 1999:239). From the perspective of the strong African belief that people must always be equal, but living in an unequal society dominated by poverty, the act justifiably protected high achievers from frivolous accusations of witchcraft by envious relatives and neighbours.

Ndebele and Shona languages are aware of the definitional differences between witchcraft and sorcery, as defined in English, but do not have appropriate terms to differentiate the two, resulting in them being used interchangeably. ${ }^{7}$ The Zimbabwean academic and traditionalist, the late Professor Gordon Chavunduka (1980), pointed out that:

Muroyi [Shona] or umthakathi [Ndebele] means witch, a sorcerer, a poisoner, a person who fails to carry out the necessary rituals for his dead relatives, a person who commits an anti-social act or even just a troublemaker. (p. 132) ${ }^{8}$

However, some African languages can differentiate sorcery from witchcraft (Parrinder 1976:123). Even among the Shona and Ndebele, sorcery and witchcraft are different. Chavunduka (1980:132) explains in a footnote that the Shona and Ndebele recognise a witch who operates at night, while a witch (being a sorcerer) operates during the day. Witchcraft is believed to stem from an involuntary, abnormal, intrinsic, personal nature of being a witch (Manala 2004:1496). In many cases, their mere presence is considered enough to trigger upheavals such as scaring babies, causing sickness and causing misfortunes to people around them. They are traditionally believed to possess within themselves destructive powers activated by their mere presence, their wish to harm, their words or even feelings of annoyance and jealousy towards an individual or groups of individuals (Chavunduka 1980:132).

\section{The two terms are also used interchangeably in this study.}

8.Prof. Chavunduka led the Zimbabwe National Traditional Healers Association (ZINATHA) and unsuccessfully campaigned for the repealing of the Witchcraft Suppression Act, arguing that there were credible evidences for the reality of witchcraft, for example, Chavunduka 1980:141. Like many traditional Africans, Chavunduka felt that the Act shielded those who practiced witchcraft from being Chavunduka felt that
brought to book.
Sorcery, on the other hand, is a voluntary employment of harmful schemes and evil magic to harm someone owing to envy, malice or jealousy (Chavunduka 1980:132; Manala 2004:1494-1496). Simply stated, witches use indwelt evil powers to bewitch, while sorcerers use external magical instruments. As Manala (2004:1496) highlights from Nyirongo, sometimes acts of witchcraft and sorcery merge, making it difficult to clearly distinguish between the two. Generally, witchcraft is seen as a feminine trade, while sorcery is strongly linked to men (Manala 2004:1494; Parrinder 1976:124).

In essence, witchcraft and sorcery are feared because of their attested preoccupation with destruction of life. Explains Manala, 'Witchcraft raises intense fear and revulsion because it destroys human life, human community and shatters dreams and visions of individuals and societies' (Manala 2004:1500). To an African, witchcraft is synonymous with destruction and death. Studies on witchcraft in Africa, particularly among Western scholars, tended to view belief in witchcraft, and consequently the fear thereof, as mere superstition and/or a way of coming to terms with unnatural and unexplainable misfortunes (Chavunduka 1980:135). These assertions may indeed have demonstrable merit. However, they overlooked an important fact as noted by Chavunduka (1980:141), the reality of people who actually make attempts to practice witchcraft and perform activities causing other people to become sick or even die. Witchcraft cannot therefore just be confined to bizarre stories of flying witches, dancing naked or eating corpses in graveyards at night. The fact is, some people do indeed approach spirit mediums employing them to cause harm or death to others. There are numerous news reports of ritual killings with the intention of converting the killed persons into zombies commonly called tokoloshies and imikhoba (izinto or izituhwane) in Ndebele (Bozongwana 1983:38) and zvivanda (zvidhoma or zvishiri) in Shona. These zombies are agents of witches sent to undertake various missions on behalf of their witch masters (Manala 2004:1494). In Zimbabwe, stories abound of people who maimed themselves or parents who either killed or maimed their own children or relatives for use in the creation of magical charms that bring wealth. For this reason, at every death, traditional Africans consult traditional healers to establish the cause of death. This makes witchcraft a feared trade, and witches are labelled as anti-progress: they eat their own children, thus hindering family growth; they cause infertility; they block rains to cause drought; and they work against economic progress in families and communities. These actions are prompted by evil, malice, envy, jealousy and even greed, which ultimately make them enemies of progress.

Perhaps the most disconcerting part of witchcraft among Africans is that no one is immune from the vicious circle of witchcraft accusations. Understandably, the rich and powerful may be accused of amassing their wealth through the power of witchcraft. This however does not spare the poor who may be accused of blocking the progress of their relatives and neighbours to remain poor like the witchcraft practitioner. It is not strange to hear the Ndebele and Shona 
blame their poor relatives for a misfortune or sickness that scuttles the progress of a brilliant child in his and/or her school work. The reasoning for a poor relative to bewitch a progressing relative's child is to ensure both families remain poor. Similarly, theft, murder and any other anti-social behaviour can be blamed on witchcraft's evil spells to make them social outcasts and lose respect in community, or are being punished for wrongdoing. Churches of Christ in Zimbabwe members interviewed attested knowledge of these assertions.

\section{The Christian awareness of witchcraft in Zimbabwe}

Respondents for this study from a COCZ congregation, in the city of Bulawayo, reflected a positive consciousness to the reality of witchcraft. As will be shown in this section, these believers seemed to repeatedly affirm ATR adherents' depictions. One respondent defined a witch as a 'person with an evil spirit who wants to kill others through evil medicine and even words and evil-wishes and destructivetendencies'. This resonated with literary dispositions presented above. Thus, fear of witchcraft emanated from their belief that witches have spirits they use to harm other people. Respondents reported that witches are malicious and harmful to people in society and can strike people, animals and houses with lightning. Respondents however could not distinguish between witchcraft and sorcery as their languages did not have elaborate terms for distinguishing the two.

Concerning how one can become a witch, participants spoke of inherited ability. Shona, uroyi hwedzinza, or Ndebele, indlozi elibi, is understood as hereditary witchcraft (Bozongwana 1983:40). Respondents further highlighted one's initiation into witchcraft; hence, the Shona speak of uroyi hwokuromba or uroyi hwekutemerwa nyora, referred to in Ndebele as ubuthakathi bokucatshelwa. Witchcraft by initiation can be voluntary or involuntary. Whatever form witchcraft takes, its intention is to cause destruction to others. The destruction can be caused out of sheer malice or in order to benefit from it. Thus, respondents simply confirmed popular mythological stories about witches, showing an unquestioned belief in witchcraft. One respondent narrated that witches seek supernatural powers to perform mysterious acts like flying in baskets. She cited common stories of witches found naked in other people's homes in the mornings after being defeated by the antiwitchcraft traps of their victims.

This attests deep attitudes of ATR beliefs among COCZ Christians. Churches of Christ in Zimbabwe respondents believed witches have sinister powers to fly in reed baskets, grass brooms, walk naked and ride on nocturnal animals and birds. Respondents even narrated cases of witches that were detected, subdued and caught by people with strong antiwitchcraft mechanisms. Respondents highlighted how witchcraft functions in ordinary life, and how traditional healers trap witches in their homes. This was the same with what literature says on terrorising agents like tikoloshes and other harmful inflicting things. Curses among the Ndebele are performed by swearing or making an oath, ukufunga ijoyi, or Shona, kupika. Words are used, or to some extent harm is inflicted by actions such as stealing someone's underwear and placing a curse on it to hinder their prospects for marriage and fertility. One Christian lady in the interviews professed to have been cursed by her stepmother and she struggled in her marriage to get a baby until some spiritual person reversed the curse.

Similarly, candidates sitting for an examination were reportedly cursed by others bringing bizarre objects and even animals such as cats to aid them to pass their examinations. Respondents also reported of people who lost their sight or intelligence owing to witchcraft. They also reported of acts of witchcraft that are not true as perpetrators play mind games to disorient competitors such as wearing amulets during a running competition or a boxing match. One lady narrated that jealous people can disorient an intelligent person or derange an educated person to become a tramp. Bewitching a person to fail however, did not translate into improvement of the economic conditions of the perpetrator but simply hindered the victim from surpassing the witch.

In this, respondents simply highlighted the destructive forces of witchcraft to register their own innate fears of witchcraft in their own personal and family lives.

\section{The Christian experiences of witchcraft in Zimbabwe}

Some of the respondents reported that they had personally experienced acts of witchcraft in their own personal lives. One church elder narrated an escape from suspected setting of witchcraft on meat in a relish. Whether the meat was poisoned or was treated with magic is not clear. He had been previously cautioned not to eat food from this relative by his father. The researchers did not establish whether the elder was already a Christian by the time this happened. His narrative however demonstrated that the fear of witchcraft in Africa, even among Christians, is not a baseless superstitious act. This case was convincing enough to establish suspicion of witchcraft which someone can testify in public. As Chavunduka (1980) argues:

$[A]$ person who accuses another of witchcraft may be referring to 'indirect' sorcery, that is, medicines, poisons or strange objects planted somewhere with the intention of harming those who see them or come into contact with them. These are techniques which can injure or do psychological harm to those who believe in them. (p. 134)

Other Christian correspondents narrated of being victims of witchcraft in their post-Christian conversion lives. A middleaged lady who has been a Christian for over 23 years, with leadership responsibilities in the church, testified that she experienced witchcraft when spiritual agents, tikoloshes, were sent to beat her up in the final days of her first pregnancy 
while at her husband's homestead. ${ }^{9}$ She narrated that she was 19 years of age at that time, when she collapsed and lost consciousness. It is however common custom that the first pregnancy and child birth is taken care of by the maternal family. She believes that an in-law who did not want her in the family was responsible for her ordeal. Her family pledged that she needed to undergo fumigation with special herbs, Shona, kupfungaidzirwa, to be released from the effects of tikoloshes. The attack was too strong for the traditional healer they consulted. She could not regain consciousness and had to be taken to the clinic where she was induced in her unconscious state to give birth. She ended up in the intensive care unit (ICU). Her condition could not be explained medically. She was unconscious for more than a week in the ICU, until her father demanded to take her to a certain traditional healer who helped her regain consciousness after administering chipfungaidzo (fumigation). The traditional healer also revealed that her ancestors wanted to inhabit her as their host. She would become a diviner, and a healer, meaning part of the treatment included initiation into the practice. Being a Christian, she refused to be initiated. Rather she insisted on being taken to church for Christian prayer and fasting, to receive total healing. For the following 15 years, she resorted to prayer and fasting to dispel the occasional spells and/or attacks of dizziness, dzungu, in Shona. She would even go to church and pray alone. She testified that her late teenagerhood experiences have lived with her throughout her adult Christian life. Hence, she has learnt to successfully command the devil out of her life using the name of Jesus Christ during periods of attacks, and she encourages other Christians under the influence of witchcraft to personally and individually practice the same. It seems she combined modern medical technology and Christian prayer and fasting although her testimony underplayed other treatment options. This testimony from a committed and active Christian who has been a believer for a lengthy period shows that the fear of witchcraft among both Christians and non-Christian Africans cannot be dismissed as a mere myth or psychosomatic sickness.

Further, an elder and his wife, who are both in the leadership at the congregation, reported a neighbour telling them of her many unsuccessful attempts to 'enter' their home. No further elaborations were revealed on what failed attempts to 'enter' meant, but the couple concluded that it was an act of witchcraft because earlier on the same person had complained to the couple for cutting down a big tree in their yard when they first moved in. The Christian couple concluded that the tree was the meeting place for community witches including the neighbour (cf. Bozongwana 1983:39-40). Cutting it down removed the witches' rendezvous.

From respondents' personal narrations, witchcraft is a real phenomenon Christians live with and constantly battle with throughout their Christian walk, which necessitates a discussion about how to overcome witchcraft.

9.It is common to hear stories of beatings by tikoloshes among the Shona and the Ndebele, the effects of this include suffering a heart attack, paralysis or confusion among others.

\section{Signs of overcoming the fear of witchcraft}

Based on the outcomes of the focused group discussions (FGDs) and in-depth interviews, there were some notable signs of attempts to meaningfully engage the reality of witchcraft among COCZ Christians. All respondents expressed conviction that as Christians they ought to only rely on Christ for their security from witchcraft. This was expressed clearly by the woman who reported being beaten up by tikoloshes in the third trimester of her pregnancy. In the face of grave risks to her life and her recently born son, she rejected the traditional healer's prescription; she opted to be taken to her church for prayers. Perseverance in prayer and fasting managed to deal with her periodic spasms of dizziness as her encounter with tikoloshes. During the interview, she exuded confidence and commitment that her reliance was in God only. She made it her personal responsibility to confidently and consciously fight the powers of witchcraft and to overcome them in her life. In concurrence with her, other respondents cited reliance on prayer, fasting and Bible reading.

Further, another respondent expressed confidence in Christ saying: 'If you have accepted Jesus Christ as your personal Saviour, and you have an understanding of the Word, the effects of witchcraft can come to an end in your life'. The respondent indicated confidence of overcoming the power of witchcraft if one has Christ as his and/or her Saviour. The meaning of 'understanding of the Word' was left unpacked. It can be interpreted that on top of accepting Christ as a Saviour, one must take personal responsibility for developing a matured outlook towards life by reading the teachings of the Bible. Indeed, other respondents mentioned reading, quoting, reciting and claiming the words of the Bible like Psalm 91. A church elder calmed her daughter who feared that her intelligence would be stolen by other students using witchcraft and cause her to fail her exams by advising her to keep reciting Psalm 91. Although this seems to resemble the way Christ overcame the devil's temptations in Matthew 4, it can be asked if these Christians quote and recite the words of the Bible to affirm a relational dependence on God to defend them, or they use biblical words in a form of incantation as if they have magical power of their own to drive away the witches. At times, it is not clear whether understanding the word of God refers to how to magically use the words of the Bible or to grow in a personal relationship with God through applying the teachings of the Bible to one's life.

Connected to the recital and use of biblical words is a method captured by the infamous local gospel song, Go back to the Sender, whereby in the name of Christ curses are commanded to return to their senders. The Ndebele say, impinda muva yingozi, to express the belief that a returning curse hits its original sender much harder than it would have hit its original victim. Therefore, 'Go back to the sender' is an ATR concept. It is an ATR method to redress witchcraft problems by reversing 'missiles' to their originators. The use of the 'go 
back to sender' by Christians shows there is an adoption of ATR methods in African Christian response to witchcraft. Previous studies show that many Christians easily adopt and incorporate the ATR worldview (Biri 2012:10; Magezi \& Banda 2017:4-5). While certain Christian reference points may be assimilated, the spiritual outlook remains the same as before.

Some respondents clearly stated that to solve the problems of witchcraft, they needed to remain in Christ, and to avoid mixing their faith with traditional approaches to healing. One respondent emphatically stated: 'In all circumstances and at all times, I stand in Christ'. This seems to indicate dependence on God arising from having a personal relationship with him.

Still, at times, personal responsibility is emphasised in a manner that ends up elevating individual effort than reliance on God's protective power. One respondent indicated that one's spiritual standing regulated the effect of witchcraft in their lives. Hence, giving generously to others was cited as a protective measure from witches. The problem with this view is that security from witchcraft seems to be a form of reward for good behaviour instead of something God gives to all Christians. The conviction reflected by this position is that when one is holy and doing good things they are safe from witchcraft. Ultimately, individual and personal holiness become mechanisms of defence against witchcraft rather than dependence on God. Therefore, when attacked by witchcraft, such Christians would blame themselves for lack of holiness. Ultimately, just like in ATR, Christians demonstrated dependence in their personal efforts rather than in God. Instead of faith in God's protective power, efforts were invested in personal efforts such as holding on to objects given by the prophets, careful adherence to recital words or rebuking the devil. Therefore, confidence is placed on human effort instead of God's power.

\section{Signs of being overcome by the fear of witchcraft}

However, the above noted signs of overcoming the fear of witchcraft paradoxically indicate being overcome by the fear of witchcraft. The apparent victory over witchcraft is crippled by the ATR spiritual framework that continues to wield enormous influence on COCZ members as reflected by their responses to the FGDs and in-depth interviews. Fundamentally, the problem rests with the spiritual outlook of COCZ Christians who appear to be regulated by fear of witchcraft instead of the victory in Christ (Heb 4:12). Apart from references to dependence on Christ, the attitude of COCZ interviewees towards witchcraft remained comparably similar to non-Christian Africans. Particularly, respondents recounted common traditional beliefs and stories about witchcraft as if true without any critical reflection of both their authenticity and reality. This appears to reflect the heavy extent to which consciousness of the power of witchcraft bears in the religious consciousness of Christians, resulting in a religiosity that is motivated by attaining magical power instead of cultivating a deeper personal relationship with God (Bhebhe 2013:52).

Further, a respondent complained that COCZ 'pastors are unable to save us from witchcraft, because witches operate in the church (COCZ)'.10 As Asamoah-Gyadu (2015:24-25) shows, missionary mainline churches in Africa have failed to take witchcraft seriously, resulting in mainline Christians seeking help outside their formal churches. The respondent indicated that witches freely operate in the COCZ because its pastors lack spiritual and/or magical powers to detect witches in the church. This poses controversy on how one can be a Christian and still practice witchcraft. However, this is not a uniquely COCZ problem. Biri's (2012:3) study of Pentecostal Christians in Zimbabwe shows the prevalent irony of claiming to be 'born-again' and undergoing several deliverance sessions and yet speaking of witchcraft activities and those haunted by evil spirits within the church.

Churches of Christ in Zimbabwe members expressed a longing for pastors who are spiritually alert to the presence of witches. In fact, another respondent wanted to see witches and wizards publicly exposed in the church but was dismayed that it was not happening, which in turn gave witches a free-roaming license in the COCZ. This represents a problematic call for witch-hunting in the church, which is a common thing in ATR. ${ }^{11}$ There were murmurs that COCZ as a church does not permit the gift of prophecy through which witchcraft could be detected, exposed and exorcised. In concurrence, other respondents admired what happens in prophetic African Independent Churches (AICs) and prophetic Pentecostal churches where witches are detected, caught and delivered. This statement did not just reflect a very low estimation of the spirituality of the church's pastors but also the great power of the witches and wizards that allows them to thrive in a church. Consequently, such believers have very low confidence in both their ministers and the church. Other respondents strongly asserted that witches and wizards should be quietly dealt with, but the acts denounced publicly, without exposing individuals but condemning the evil act. Indeed, as highlighted in the discussions, owing to spiritual disgruntlement, COCZ had lost many members to AICs and Pentecostal prophets. Prophetic churches were viewed as better because of their prophetic diagnosis, prognosis and prescription to people's spiritual problems. However, Pentecostal prophets tend to validate and reinforce the African spiritual insecurities instead of challenging them and leading believers to a reconstructed worldview informed by Christ's victory on the cross (Asamoah-Gyadu 2015:25; Magezi \& Banda 2017:7).

However, the concerns of these believers must not be taken lightly. There is some legitimacy to the respondents' disgruntlement with COCZ. Respondents reported seeing

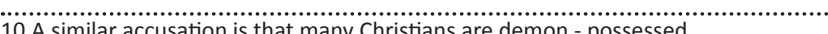
11.Incidentally, Zimbabwe has witnessed the proliferation of controversial professional witch-hunters called Tsikamtanda who roam around rural villages purporting to conduct witch-hunting and cleansing ceremonies. 
fellow church members who constantly consult traditional healers and diviners. They noted that in prophetic AICs such actions would never happen, as the prophets would quickly detect and expose a person who has just come from consulting traditional practitioners against the faith of the church. To the respondents, COCZ lacks seriousness by failing to detect and expose such double standards among its followers. Some respondents felt that COCZ church leaders deliberately suppressed prophecy and discernment in the church because of fear that the prominent church leaders who practice witchcraft would be detected by younger members of the church. This implied that some church leaders also practiced witchcraft, which further demonstrated the very low confidence of the members in the church as an institution. However, the mere notion of Christians who also practice witchcraft raises serious soteriological questions that need to be addressed in a separate study.

Furthermore, respondents indicated that they had seen fellow church members struggle under the weight of witchcraft, while COCZ was unable to help them. The troubled believers ended up receiving help from the prophetic Pentecostal churches. Subsequently, the respondent presented COCZ as unable to deal with the congregant's struggles against witchcraft.

In this regard, it can be concluded that COCZ has not adequately helped its members to deal confidently with their fears of witchcraft. And therefore, members either return to their former ATR practices or seek help from prophetic churches. This reflects the extent to which the church has failed to address their worldview and their spiritual needs. The failure of COCZ to adequately empower its members to respond confidently to their fear of witchcraft resulted in split-ecclesiological personality and split-loyalty among its members. Split-ecclesiological personality, as publicly they consider themselves members of COCZ (the church of their Christian conversion, which will bury them when they die) but privately are members of prophetic churches where they find the daily solutions to their struggle against the fear of witchcraft. There is split-loyalty in the sense that while they officially submit to their COCZ pastors, yet inwardly the prophetic pastors are the real spiritual heroes they turn to when in crises. Thus, there seems to be a serious disconnect between COCZ and the daily life and spiritual struggles of the members.

\section{Plugging the faith leak by emphasising the transcendence and immanence of God in a Christian}

Witchcraft leads Christians into what Jacobs (2001:27) calls 'faith leak' as Christians profess belief in God but fear people involved in occult (or suspected to be involved in witchcraft). Faith leak captures a loss of faith or even a crisis of faith created by doubting God's power to enable believers to overcome their fear of witchcraft. Christians who are overwhelmed by the fear of witchcraft tend to retreat to ATR practices such as consulting traditional healers or approach prophets who prescribe them magical articles such as anointed oil and anointed water.

Among many foundational theological issues at stake is a poor understanding of God. In ATR, God is viewed as an impersonal transcendent mystical being accessed through the mediation of the ancestors whose power in the life of the believer is mediated through magical charms and good works (Magezi \& Magezi 2016:2-3). Therefore, an important starting point is in addressing the resilience of the fear of witchcraft and plugging the faith leak in the COCZ by a sound understanding of God, particularly the doctrine of the immanence and transcendence of God.

Magezi and Magezi (2016:1) propose that 'immanence and transcendence of God amplified in Christ can influence African Christians' behaviour to mirror Christ, and therefore change society'. However, a sound understanding of the immanence and transcendence of God is also critical in enabling African Christians to challenge the resilience of the fear of witchcraft. Churches of Christ in Zimbabwe believers need to be awakened to the fact that God in all his mightiness is directly involved in the lives of all Christians' beliefs. The doctrine of immanence and transcendence describe how God in his infinitude relates to his finite creation. Horton (2011:331) explains that in the 'Trinitarian economy, God is simultaneously transcendent and immanent, utterly distinct from creation yet actively involved in every aspect of its existence and preservation'. The transcendence of God is expressed by attributes such as eternity and omnipresence that depict God's distinction from his creation by declaring that he exists beyond time and space and is ungoverned by them. God's transcendence is affirmed by Bible passages that declare God's absolute attributes such as unlimited by space and time (Ps 90:1-4; 139:7-8), as self-existing (Rm 11:35-36) and as dwelling in absolute holiness and righteousness (1 Tm 6:16). The transcendence of God describes his divine distinction and separation from his creation, including human beings (Erickson 1998:327-329; Grudem 1994:267).

On the contrary, immanence emphasises God's close presence and interaction with his creation. Says Horton (2011:256): 'Although God transcends time and space, he enters both freely as through an open door that he has created'. If transcendence can be taken to mean God's beyondness, then immanence means his nearness. Horton further adds, 'More than this, even enters must be understood analogically, since God is already present in every moment and permeates every place' (Horton 2011:256). To say God enters space and time must be expressed in the light of his omnipresence. In other words, his beyondness also includes his nearness, and vice versa. God who exists beyond the limit of time and space also participates in time and space. Grudem explains that the 'God of the Bible is no abstract deity removed from, and uninterested in his creations' (Grudem 1994:267). Rather, the 'Bible is the story of God's involvement with his creation, and particularly the people in it' (Grudem 1994:267). 
The transcendent God, while different from his creation, is a relational God who relates and interacts with his creation.

In the New Testament, the immanence of the transcendent God is articulated in the incarnation of Christ, when God became a human being and dwelt among his people. In a context dominated by the fear of witchcraft, implications of the immanence of the transcendent God are presented by Magezi and Magezi (2016) as follows:

... in contrast to the traditional African worldview of God as the creator, whose immanence within humankind is mediated through multiple spiritual power, ... in and through Jesus Christ, God the originator of everything stepped down (from his eternal transcendent and infinite existence) into the space and time of human existence in order to save humanity. (p. 4)

Put differently, Jesus Christ, not ancestors or magical charms, is the mediator of God's presence to humanity. Churches of Christ in Zimbabwe Christians need to be helped to firmly believe and stand on the fact that the presence of God is not mediated through religious objects but through Christ his Son (Col 2:9). According to Erickson, our understanding of the 'immanence and transcendence [of God] has definite practical implications for both the Christian's lifestyle and the conduct of one's ministry' (Erickson 1998:329).

Churches of Christ in Zimbabwe believers must awaken to the abiding presence of God in their lives through the Holy Spirit, the third person of the Trinity. Scripture presents Christians as the temple of the Holy Spirit (1 Cor 3:16; 6:19) which means that the triune God is resident in the believer through the Holy Spirit. A sound theology of the Holy Spirit is necessary to the understanding of the immanence of God in a context of the fear of witchcraft.

Furthermore, the sacraments of baptism and the Lord's Supper can, with due critical carefulness, function to draw the attention of COCZ believers to the abiding presence of God in their lives. Churches of Christ in Zimbabwe holds to the believer's baptism by immersion and the weekly observance of the Lord's Supper. Indeed, there are varying theological interpretations of baptism and the Lord's Supper. However, as practiced within COCZ, the sacraments can be used to address the fear of witchcraft by strengthening believer's confidence in Christ by highlighting God's immanence to the believer. Firstly, the realisation that some members suspect fellow Christians of practising witchcraft raises the soteriological questions of how one can be a Christian, be a temple of the Holy Spirit and be possessed by the spirit of being a witch. Secondly, considering that baptism symbolises death, burial and resurrection in Christ, it should force Christians to critically dialogue with what it means to be in Christ and yet live a life dominated by the fear of witchcraft. To dwell in Christ, the Immanuel - God is with us - as well as be indwelt by him and the Holy Spirit should awaken Christians to the immanence of the transcendent God to the believer. Thirdly, COCZ's weekly participation in Lord's Supper, in addition to being a memorial of the death and victorious resurrection of Christ, should challenge
Christians to critically dialogue with what it means to be weekly hosted by the resurrected Christ at his holy table (1 Cor 10:31) and yet live lives perpetually dominated by the fear of witches and wizards. These sacraments in addition to calling Christians to be true Disciples of Christ, also challenge African believers to a transformed worldview oriented on the immanence of the transcendent triune God. The sacraments remind Christians that they live in the very presence of God. God's immanence, through his incarnate Son demonstrates that he wants to be involved in the lives and affairs of his people and he wants them to trust him only. Jacobs (2001:27) states: 'As Christians, our destiny is in God, and our lives are governed by grace and mercy ingrained into our lives through the blood of Jesus Christ'. The various biblical texts that ban practicing magic (Dt 18:10-11; Lv 18:21) demonstrate God's commitment and ability to secure the believers from their fears of witchcraft.

Furthermore, considering the role of evil actions such as jealousy, gossip, slander and cheap scapegoating in witchcraft accusations, the fear of witchcraft demands an ethical response. Van Rooy (1999:239) highlights that in Africa, it is often believed that excelling beyond others happens by using magic or witchcraft. However, Christians are called to desist from evil attitudes such as jealousy, malice and covetousness towards the successes of other people (Ex 20:17). Rather, they must celebrate and rejoice with them ( $R \mathrm{~m} \mathrm{12:15).} \mathrm{Furthermore,}$ to fight the epidemic of witchcraft, a sound theology of work, human development and sustainable development, among many others, are needed to empower poor Africans to adopt meaningful responses to poverty that look beyond witchcraft (1 Th 4:11-12).

However, any workable theological and doctrinal response to both the belief in witchcraft and the fear thereof among Christians must take witchcraft seriously. For, ' $g$ ]rasping the power and influence of evil, including witchcraft, is critical, not only for realistic pastoral care, but also for understanding African responses to the gospel throughout Christian mission history' (Asamoah-Gyadu 2015:23). A doctrine of God that will plug the faith leak created by the fear of witchcraft must treat the African belief and fear of witchcraft with great seriousness. Firstly, it must recognise that witchcraft belongs to a host of cultic schemes used by the devil to harass and suppress God's people (2 Cor 2:11; Jacobs 2001:40). Secondly, it must open up the church's eyes to the forms of spiritual warfare in the church today, and to prepare it to articulate and exorcise the magical issues involved in its midst. As witchcraft cannot be separated from existential issues in human well-being, the COCZ needs to assert itself to issues of magic and luck which have pushed many into acquiring charms to acquire riches. Thirdly, it must enable believers to critically discern and distinguish reality from superstition. When worship services become preoccupied with manifestations of demons instead of worshipping God, the end result is endless pursuit of superstition. The resilience of the fear of witchcraft in the African church demands that more be done 'to prepare and 
equip ministers and theologians for meaningful service to black African Christians' (Manala 2004:1509).

\section{Conclusion}

The fear of witchcraft can be attested among many Christian believers everywhere. For Christians, there is need to realise that the church is not a victim of the spiritual warfare but that the church is a militant institution in the battle for souls, and thus cannot be ignorant of the devil's schemes if it can be effective in its exploits. In this way, the church needs to further assess why Christians are afraid of witchcraft. As Jacobs (2001:26) state, many Christians are afraid of witchcraft because 'many believers come from a lineage of superstition. This lends strength to our fear of being cursed by witches'. In all, members need to be assisted to navigate the path of superstition before they can overcome witchcraft and become fully committed Christians.

Overall, the fear of witchcraft is a doctrinal issue that thrives on a worldview insufficiently informed by the doctrine of God. It is proposed that critical reflection on, among other themes, the doctrine of the immanence of the transcendent triune God be seriously and urgently considered among the COCZ Christians.

\section{Acknowledgements}

The authors wish to sincerely thank the Bulawayo Pastors' Forum of the Churches of Christ in Zimbabwe for allowing them to conduct the research in one of their churches and the respondents for their unconditional participation in the focus group discussions.

\section{Competing interests}

The authors declare that they have no financial or personal relationships which may have inappropriately influenced them in writing this article.

\section{Authors' contributions}

C.B. and G.M. equally contributed to the research and writing of this article.

\section{References}

Asamoah-Gyadu, J.K., 2015, 'Witchcraft accusations and Christianity in Africa' International Bulletin of Missionary Research 39(1), 23-27. https://doi.org/ $10.1177 / 239693931503900107$

Baker, W.R., 2009, Evangelicalism \& the Stone-Campbell movement, IVP, Downers Grove, IL.

Bhebhe, M., 2013, An African culture of multiple religiosity: The perspective of the Church of Christ in Zimbabwe, Lambert Academic, Saarbrucken.
Biri, K., 2012, The silent echoing voice: Aspects of Zimbabwean Pentecostalism and the quest for power, healing and miracles, viewed 03 April 2014, from http://uir.unisa. ac.za/handle/10500/6609

Biri, K. \& Togarasei, L, 2013, “.... but the one who prophesies, builds the church” nation building and transformation discourse as true prophecy: The case of Zimbabwean Pentecostal women', in E. Chitando, M.R. Gunda \& J. Kügler (eds.). Prophets, profits and the Bible in Zimbabwe: Festschrift for Aynos Masotch Moyo prets, profits and the Bible in Zimbabwe: Festschrift for Aynos Masotcha Moyo, pp. 79-94,
University of Bamberg, Bamberg.

Bozongwana, W., 1983, Ndebele religion and customs, Mambo, Gweru.

Casey, M.W. \& Foster, D.A., 2002, The Stone-Campbell movement: An international religious tradition, University of Tennessee, Knoxville, TN.

Chavunduka, G.L., 1980, 'Witchcraft and the Law in Zimbabwe', Zambezia 8(2), 129-147.

Chikowore, F., 2017, Mugabe "threatens" to seek arrest of critics accusing him of "witchcraft", viewed 13 December 2017, from https://www.news24.com/Africa/ Zimbabwe/mugabe-threatens-to-seek-arrest-of-critics-accusing-him-of-witchcraft20170902

DailyNews, 2015, 'Satanism scare hits Harare school', viewed 14 May 2017, from https:// www.dailynews.co.zw/articles/2015/09/29/satanism-scare-hits-harare-school

Erickson, M.J., 1998, Christian theology, 2nd edn., Baker Academic, Grand Rapids, MI. Grudem, W.A., 1994, Systematic theology: An introduction to biblical doctrine, IVP, Leicester. Horton, M., 2011, The Christian Faith: A systematic theology for pilgrims on the way, Zondervan, Grand Rapids, MI.

Jacobs, C., 2001, Deliver us from the evil, Regal/Gospel Light, Ventura, CA.

Magezi, V. \& Banda, C., 2017, 'Competing with Christ? A critical Christological analysis of the reliance on Pentecostal prophets in Zimbabwe', In die Skriflig 51(2), a2273. https://doi.org/10.4102/ids.v51i2.2273

Magezi, V. \& Magezi, C., 2016. 'The immanence and transcendence of God in Adamic incarnational Christology: An African ethical reflection for the public', Verbum et Ecclesia 37(1), a1541. https://doi. org/10.4102/ve.v37i1.1541

Manala, M.J., 2004, 'Witchcraft and its impact on black African Christians: A lacuna in the ministry of the Hervormde Kerk in Suidelike Afrika', HTS Teologiese Studies/ Theological Studies 60(4), 1491-1511. https://doi.org/10.4102/hts.v60i4.635

Mapimhidze, R., 2014, A mountain that swallows people, viewed 21 September 2017, from https://www.newsday.co.zw/2014/01/mountain-swallows-people/

Maza, C., 2017, Zimbabwe's eccentric president Mugabe accuses his deputy of using witchcraft against him, viewed 13 December 2017, from http://www.newsweek.com/ zimbabwe-president-robert-mugabe-my-rival-used-witchcraft-against-me-705947

Mbiti, J.S., 1969, African religions and philosophy, Heinemann, London.

Mswazie, W., 2017, Man fatally stabs father over witchcraft, viewed 26 October 2017, from http://www.chronicle.co.zw/man-fatally-stabs-father-over-witchcraft/

Murch, J.D., 2004, Christians only: A history of the restoration movement, Wipf and Stock, Eugene, OR.

News24, 2017, Mugabe says fired deputy plotted via witchcraft, viewed 13 December 2017, from https://www.news24.com/Africa/Zimbabwe/mugabe-says-fireddeputy-plotted-via-witchcraft-20171108

Nyathi, P., 2001, Traditional ceremonies of Amandebele, Mambo, Gweru.

Osei, M.A., 2003, 'Witchcraft in the religion of the Hlubi of Qumbu: Focusing on the issues of sickness and healing in the society', DLitt et Phil thesis, University of South Africa, Pretoria.

Parrinder, G., 1976, African traditional religion, Greenwood, Westport, CT.

Saunyama, J., 2016, Chigwedere witchcraft case, litmus test for the law, viewed 26 October 2017, from https://www.newsday.co.zw/2016/10/chigwedere-witchcraftcase-litmus-test-law/

Sibanda, M.M., 1981, Sesitshaye kwazwela, Mambo, Gweru.

Sigogo, N.S., 1962, USethi ebukhweni bakhe, Mambo, Gwelo.

Sigogo, N.S., 1967, Gudlindlu mntanami, Mambo, Gwelo.

Swancer, B., 2017, Vanishings and high strangeness at Africa's cursed mountain, viewed 21 September 2017, from http://mysteriousuniverse.org/2017/01/ vanishings-and-high-strangeness-at-africas-cursed-mountain/

Taringa, N., 2006, 'How environmental is African traditional religion?', Exchange 35(2), 191-214. https://doi.org/10.1163/157254306776525672

The Chronicle, 2017, School girls collapse in Satanism scare, viewed 14 May 2017 from http://www.chronicle.co.zw/school-girls-collapse-in-satanism-scare/

The Standard, 2014, Mystery over disappearance of tourist in Nyanga deepens, viewed 01 September 2017, from https://www.thestandard.co.zw/2014/01/12/ mystery-disappearance-tourist-nyanga-deepens/

Van Rooy, J.A., 1999, 'The Christian gospel as a basis for escape from poverty in Africa', In die Skriflig 33(2), 235-254. https://doi.org/10.4102/ids.v33i2.626 